\title{
Quality of Public Services in the Capital Investment and Integrated Service of South Kalimantan Province
}

Dita Rebana Hidayat Putri ${ }^{*}$, Asmaji Darmawi, Jamal Uddin

Master Program of Government Science, Lambung Mangkurat University, Banjarmasin, Indonesia

DOI: $10.36348 /$ sijlcj.2020.v03i06.007

| Received: 29.05.2020 | Accepted: 06.06.2020 | Published: 12.06.2020

*Corresponding author: Dita Rebana Hidayat Putri

\section{Abstract}

Public service is a duty of the government that must be fulfilled, the service performed is an activity to improve the standard of living of the people to achieve prosperity to achieve one of the objectives of the state which is to create prosperity for its citizens. This study aims to determine the quality of Public Services in the Investment Office and OneStop Integrated Services of South Kalimantan Province. The method used in this study is a descriptive method with a qualitative approach where researchers use the theory of service quality indicators from zeithaml. Data collection techniques used by researchers through observation, interviews, and documentation, and for data analysis using the theory of Miles and Huberman which starts from observation, interviews, data presentation activities and concludes data. The results obtained in this study are that based on service quality indicators from zeithaml, it can be outlined that Service Quality in the Investment Service and Integrated Services of One Door South Kalimantan Province is still not optimal, including the lack of facilities and infrastructure and the location of offices far from the city. As for services from officers, get a fairly positive response, because service officers are very proactive in providing services to the community as the applicant for permission.

Keywords: Public services, quality, and One-Stop Integrated Services.

Copyright @ 2020: This is an open-access article distributed under the terms of the Creative Commons Attribution license which permits unrestricted use, distribution, and reproduction in any medium for non-commercial use (NonCommercial, or CC-BY-NC) provided the original author and source are credited.

\section{Preliminary}

Indonesia is a country that aspires to achieve good governance. The conditions for the creation of good governance, at least include transparency, accountability, and participatory governance [1]. But when we look at the behavior of public bureaucracy in running the government system, there are so many problems encountered. The public bureaucracy in Indonesia faces complex multidimensional problems. The structure is very hierarchical, compartmentalized, and makes bureaucratic officials less able to develop creativity and innovation in the delivery of public services [2].

The government is currently trying to renovate everything to make Indonesia progress by implementing Regional Autonomy, which is meant by Regional Autonomy itself is the right, authority, and obligation of the region to regulate and manage their households under applicable laws and regulations. The implementation of regional autonomy in Indonesia is based on Law Number 22 of 1999 which has been amended to Law Number 32 of 2004 and Law Number 12 of 2008 concerning Regional Government as the basis for Regional Government in running the wheels of the Regional Government itself [3, 4].

Public service is a duty of the government that must be fulfilled, the service performed is an activity to improve the standard of living of the people to achieve prosperity to achieve one of the objectives of the state which is to create prosperity for its citizens. According to Kepmenpan 63 / KEP / M.PAN / 7/2003, concerning general guidelines for public service delivery, at least covering: a) service procedures, b) completion time, c) service costs, d) service products, e) facilities and infrastructure, and f) competency of service providers. According to Law Number 25 of 2009 concerning Public Services, Article 1 Paragraph 1 which reads Public Services is an activity or series of activities in the framework of meeting service needs following statutory regulations for every citizen and resident of goods, services, and/or administrative services provided by public service providers.

South Kalimantan Governor Regulation No 4 of 2013 concerning Public Services contained in Article 19 that the implementation of public services is obliged to prepare and set Service Standards; compile, establish 
and publish a Service Notice; provide legal certainty guarantees for service products; place competent Executors; provide facilities, infrastructure and / or Public Service facilities that support the creation of a healthy service climate; provide quality services in accordance with the principles of public service delivery; assist the community in understanding their rights and responsibilities; actively participate and comply with laws and regulations related to the administration of public services; provide accountability for services provided; account for services that have been carried out in the case concerned resign or relinquish office; fulfill the call to attend or carry out orders based on statutory provisions at the request of the coach; provide correct information related to service; and respond to and manage public complaints through mechanisms in accordance with statutory provisions.

In the South Kalimantan Governor Regulation No. 4 of 2013 concerning Public Services contained in Article 31 paragraph 2 to improve the quality of public services, the organizer must pay attention to the commitment of the Operator and Implementer; change of mindset towards service functions; service user participation; trust; Organizers and Implementers' awareness; openness; budget availability; a growing sense of belonging; community satisfaction survey; honesty; realistic and fast; feedback and public relations; courage and habit of receiving complaints; and success in using the method.

The substance of public services is always associated with an activity carried out by a person or group of people or certain agencies to provide assistance and convenience to the community to achieve certain goals. This public service is becoming increasingly important because it is always in touch with the general public who have a variety of interests and goals (Edward III, 1980). Therefore public service institutions can be carried out by the government and non-government. If the government is a bureaucratic organization in the public service, then the government bureaucracy organization is the leading organization that deals with public services.

Government institutions provide services, the most important thing is how to provide assistance and facilities to the community to meet their needs and interests. A quality service provided to the community requires the efforts of all employees, and not only from officers in the "Front Office". Thus, this effort is not only demanded by those who are dealing directly with the community in producing services that reflect the quality of the employee's attitude, but also from employees in the "Back Office" who produce behind the scenes services that are not visible to the public. In the concept of community service performed by Government Agencies must be carried out by all employees,
Community service reflects the whole approach of an employee in a government agency. The essence of community service is the attitude of helping, friendly, and professional in providing services or products from an agency that satisfies the community and causes people to come back to beg for the services of the agency [2]. Community service requires every element in the institution to empathize with the community. Empathy implies the ability of government bureaucrats to place themselves on the part of the community and see things or problems for the community. Through empathy carried out by employees will require patience in providing services to the community [5].

The Office of Investment and Integrated Services of One Door South Kalimantan Province, there are several types of Licensing Sector, namely Licensing in the Field of Health, Public Works and Spatial Planning (PUPR), Social Affairs, Labor, Transportation, Investment, Maritime Affairs, and Fisheries, Tourism, Agriculture Livestock Sector, Agriculture, Plantation, Forestry, Energy and Mineral Resources, Trade, Industry, Education, Cooperatives, Environment, Land, Library and Archives sectors.

In connection with the aforementioned matters, in the Office of Investment and Integrated Services of One Door South Kalimantan Province, researchers see several problems, namely lack of human resources (HR), which employees serve the community for taking care of permits play a dual role as front office and backoffice staff so that to serve the public is slow, service information systems are manual because they have not used a database (unstructured), online licensing applications have not been operated, and lack of adequate facilities and infrastructure to improve these services to provide certainty in-service time, security and comfort. Therefore, this article aims to describe the quality of Public Services at the One-Stop Investment and Integrated Service Office of South Kalimantan Province.

\section{RESEARCH METHODS}

This research uses a qualitative approach. The reason researchers choose a qualitative approach is in this study the data generated in the form of descriptive data obtained from data in the form of writing, words, and documents that come from sources or informants that are studied and can be trusted [6]. In terms of location, this research is a type of field research that is research conducted directly in the community to find and collect data. A descriptive method is used to help to know how to achieve the desired goals [7]. The research instrument is the researcher himself, the research instrument uses tools that are selected and used by researchers in gathering activities so that the activity becomes systematic and facilitated by it. Data collection techniques through observation, interviews, and documentation [8]. Data analysis was carried out since 
the beginning of the research and during the research process carried out [9].

The data obtained is then collected for systematic processing. Starting from observation, interview, then the activity of presenting data and concluding the data [10]. Data analysis techniques in this study used the Miles and Huberman model, namely; 1) Data Reduction through the selection of main points according to the focus of the study; 2) Data presentation (display data) is based on a narrative text presentation; 3) Withdrawal of Conclusions based on the context of this study, it is expected that conclusions drawn from data/information that has been successfully captured will reflect the real reality. Data validity test is performed to determine the level of confidence in the data under study. In the research the data validity test is carried out as follows; 1) Extension of observations to check or add data sources; 2) Increased perseverance to see the certainty of data and the sequence of events will be recorded with certainty and systematically; 3) triangulation techniques, and; 4) Member check to find out whether the data or information obtained and which will be used later is following what is intended by the resource person $[11,12]$. If the data found is agreed by the data giver means the data is inside [13].

\section{DISCUSSION RESULT}

Public service is defined as providing services (serving) the needs of people or communities who have an interest in the organization following the basic rules and procedures that have been established. Public service is an aspect, task, or authority of a public organization in the form of providing services to the community. In providing a form of service to the public, those who provide services must be principled that citizens have the same opportunity to obtain services [14]. Affirmed by KEP / 25 / M.PAN / 2/2004, public services are all service activities carried out by public service providers to meet the needs of service recipients, as well as in the context of doing the provisions of the legislation.

The quality of public services is understood as an effort to fulfill everything related to production, services, people, processes, environment, and the needs and desires of consumers both in the form of goods and services that are expected to meet the expectations and satisfaction of the community as customers. Quality of service, in general, must meet customer expectations and satisfy their needs. However, even though this definition is oriented towards service users, it does not mean that in determining the quality of service, service providers must comply with all the desires of consumers. The quality of service can be known by comparing service users' perceptions of the service they receive with the service they expect. Quality service can be assessed from the dimensions Services as follows:
Tangibles are the ability of a company to show its existence to external parties. The appearance and capability of the company's physical facilities and infrastructure and the condition of the surrounding environment are tangible evidence of the services provided by the company. Thus tangibles seen from the perspective of government is a devotion from the government to the community that is manifested in a service provided, where tangibles include physical facilities, equipment, personnel, and communication media such as the condition of buildings, computers, printers, etc. related to facilities and infrastructure. Based on the results of the study, the researchers found that the direct evidence here was that the facilities and infrastructure were sufficient and satisfying enough for the permit applicants (community) who came to the Investment Office and the One-Stop Integrated Services of South Kalimantan Province. The problem found was that the permit applicants believed that access to this office was far to be achieved because the office relocation factor that was originally located in Banjarmasin was moved to Banjarbaru City, then the queuing system which did not yet have a queue serial number and lack of information brochures. Based on this, it is fitting for the Office of Investment and Integrated Services One Door Prov.

\section{Reliability}

This dimension is the ability of service providers to provide services as promised precisely and reliably. The reliability of officers in providing services greatly helps the community to receive services quickly and easily. Reliability can be seen from the accuracy in serving, the ability and expertise of officers in using tools in service. Reliability is the ability to provide the promised service immediately, accurately, and satisfactorily. In this study, the timeliness of permit processing here is a mainstay (Reliability) from the service apparatus of the Office of Investment and Integrated Services One Gate Prov. South Kalimantan Reliability is the ability to provide the promised service immediately, accurately, and satisfactorily, precisely, and reliably.

Investment Officer and the One-Stop Services Office South Kalimantan Province can fulfill services according to the promised time. Based on answers from several informants, it can be seen that basically the service process provided by the Investment Service and One-Stop Integrated Services Prov. South Kalimantan according to the community is quite good. Investment and Integrated Services One Door South Kalimantan Province has provided certainty in the time of public service and added service personnel have also mastered what they have to do, and also added with various training provided by the Investment Office and One Stop Services Integrated South Kalimantan Province.

\section{Responsiveness}

\section{Tangibles (Direct Evidence)}


In Responsiveness, this dimension is a willingness to help and provide fast and appropriate services to service users, by delivering information relating to service needs. Leaving consumers waiting for no apparent reason causes a negative perception of service quality. Briefly can be interpreted as a willingness to help service users properly and quickly. The seriousness of the licensing officer in particular to provide the best service possible can be done by providing certainty about the resolution process and the response or response of the apparatus in providing services to the community.

Here the officer is right and alert in serving the permits and complaints of the permit applicants, and even in working on the permit, the officer always tries his best, but there is something that makes it constrained, is the problem of unstable internet connection which results in work that can be delayed, because now the permit processing system is online, therefore it is very influential in the process of making the permit. Even though there are such obstacles, the officer still provides a quick and best response to the applicants for permission and in the event of such interference or obstacle, the officer quickly contacts a third party, namely the internet provider so repaired as soon as possible. In this case, it should be the Office of Investment and Integrated Services One Door Prov. South Kalimantan must fix these problems, so as not to obstruct the process of officers in carrying out their duties.

\section{Assurance \\ Assurance here is knowledge, ability, courtesy, and trustworthiness, free from danger, risk, or doubt. Thus the focus of assurance is concerned with the nature of covering security, comfort, and trust. Here officers have the knowledge, ability, and courtesy in carrying out their duties, in providing information, overcoming problems, and licensing matters, all done according to service procedures in the Investment Office and the One-Stop Integrated Service Prov. South Kalimantan The guarantee provided by the service provider is related to the ability of the service provider who gives a high sense of trust to service users, the trustworthiness of the officers. If the service user is given a guarantee regarding the service.}

\section{Empathy}

This dimension gives sincere and individual or personal attention given to service users by trying to understand the desires of service users where service providers are expected to have an understanding and knowledge of service users, understand the needs of service users specifically, and have a comfortable operating time for customers. Briefly can be interpreted as an effort to know and understand the needs of individual service users. Empathy is a requirement for caring and giving personal attention to customers. The focus of attention from empathy is caring and sincere attention in providing services from the apparatus to the community. So that there is a conducive relationship between apparatus with the community, in this case, are the Officers of the Capital Investment and One-Stop Integrated Service Prov. South Kalimantan with the applicant for permission.

One major factor in service success is friendliness to service users, for example by smiling and greeting, with smiles and greetings the service user feels that he has been cared for and from there arises from the heart of the service user that service users feel comfortable with the service provided by service providers. Hospitality is not an asset, but friendliness is the key to success for service providers to establish good relationships with service users. In this case the One-Stop Integrated Investment and Service Office officer Prov. South Kalimantan, has given the best to the community as an applicant for permission, they give care and attention to each applicant who comes without discriminating who they are. This is very good because there is no discrimination process because if there is a fit of social jealousy arises between the applicants for permission. So based on the above, we can be sure that the quality of service related to care and attention is very good.

Based on the 5 indicators above, it can be outlined that the quality of services in the Investment Office and the One-Stop Integrated Services of the South Kalimantan Province is still not optimal, including the lack of facilities and infrastructure and the location of offices far from the city. As for service from officers, getting a fairly positive response, because service officers are very proactive in providing services to the community as the applicant for permission. The five dimensions of quality of public services above can also be influenced by several factors, such as organizational structure, the ability of the apparatus itself, and the service system [15]. In another concept, it is said that the organizational structure can also be interpreted as a relationship of the characteristics, norms, and patterns of relationships that occur within the executive body that have a good or real relationship with what they have in carrying out policies [16].

The organizational structure defines how tasks are divided, reporting to whom, formal coordination mechanisms and patterns interaction followed. Further said how the organizational structure has three components, namely: complexity, formalization, and centralization. Complexity means in structure organization consider the level differentiation existing in the organization including the level of specialization or division of labor, the number of levels in the organization, and the degree to which organizational units are geographically dispersed. Formalization means that in the organizational structure contains the procedures or procedures for how an activity is carried out (standard operating procedures), what can and can't 
be done. Centralization means the organizational structure contains the authority of decision making, whether decentralized or decentralized [17].

Based on the results of the study, it can be outlined that in the process of granting permits to applicants, it has a well-structured process, and must also be done as such. From the state apparatus and/or government apparatus, it is expected or demanded that there are capabilities in the form of adequate knowledge, skills, and behavioral attitudes, following the current demands for service and development [1]. Meanwhile, other concepts define abilities as traits that are born or learned that enable someone to do something mental or physical, while skills are skills related to tasks $[16,18]$.

The service system is a unified whole of a series service that is interrelated, a part of a subsidiary of a service system is disturbed then disturb island whole service itself [19]. In this case, if one of the elements of service is as high as the high cost, low quality, or length of time it will damage the image of service in a place. Some service system indicators that are determining factors in measuring the quality of public services are as follows:

1. Comfort in obtaining services related to the location of the service;

2. Clarity of information about services provided; third, protection against the impact of service results.

In this case the Office of Investment and Integrated Services One Gate Prov. South Kalimantan assured that it has provided good service in terms of system service, however, in fact, there are still permit applicants who think that the office location is not very supportive even though the facilities and infrastructure are adequate, but it is still troublesome for the permit applicants because the office location is far from the city. And also in the clarity of information, it still lacks brochures about the licensing process, but it is all covered by the ability of the licensing officers who are proactive in providing services to the applicant for permission.

\section{CONCLUSION}

The quality of public services in the PMPTSP Service can be assessed through the first 2 elements of the factors that affect the quality of public services and the five dimensions of zhetimal, among others, Tangibles, Reliability, Responsiveness, Assurance, and Empathy. Based on these two elements, it can be concluded that the quality of service in the Office of Investment and Integrated Services of One Door South Kalimantan Province is considered not optimal, including the lack of facilities and infrastructure and the location of offices far from the city. As for services from officers, get a fairly positive response, because service officers are very proactive in providing services to the community as the applicant for permission. Improving the quality of the Investment Service and Integrated Services of One Door South Kalimantan Province can be started by improving the quality of human resources and the quality of service tools. This relates to human resources. Ideally, useful training can be given, so that all Front Office staff are familiar with licensing, to improve the quality of the service and can satisfy the community as consumers or applicants for permission. In particular, the improvement of service aids here is done by looking at the condition of the facilities and infrastructure available. Thus, it can optimize online-based licensing systems and licensing applications available on smartphones.

\section{REFERENCES}

1. Agus, D. (2005). Mewujudkan Good Governance Melalui Pelayanan Publik. Yogyakarta: Gajah Mada University Press.

2. Agustino, L. (2006). Politik dan Kebijakan publik. Bandung: AIPI.

3. Ali, F., \& Baharuddin. (2013). Pengantar Ilmu Administrasi. Gorontalo: Penerbit PT BIFAD Press.

4. Hardiyansyah. (2011). Kualitas Pelayanan Publik Konsep, Dimensi, Indikator dan. Implementasinya. Yogyakarta: Gava Media.

5. Sutrisno, H. (1998). Mewujudkan Good Governance melalui Pelayanan Publik. Yogyakarta: Gajah Mada University Press.

6. Afifudin, \& Saebani, B. A. (2012). Metodologi Penelitian Kualitatif. Bandung: Pustaka Setia.

7. Kasiram. (2010). Metode Penelitian KualitatifKuantitatif. Malang: Uin Maliki Press.

8. Bungin, B. (2008). Metode Penelitian Kualitatif. Aktualisasi Metodologi ke. Arah ragam Varian Kontemporer. Jakarta: Rajawali Press.

9. Moleong, L. J. (2002). Metode Penelitian Kualitatif. Bandung: PT Remaja Rosdakarya.

10. Cresswell, J. W. (2010). Research Design Pendekatan Kualitatif, Kuantitatif, dan. Mixed. Yogyakarta: Pustaka Pelajar.

11. Yusuf, A. M. (2017). Metodologi Penelitian Kuantitatif, Kualitatif \& Penelitian Gabungan. Jakarta: Prenada Media Group.

12. Arikunto, S. (2003). Prosedur Penelitian, Suatu Praktek. Jakarta: Bina Aksara.

13. Gunawan, I. (2014). Metode Penelitian Kualitatif Teori dan Praktik. Jakarta: Bumi Aksara.

14. Moenir, A. (2008). Manajemen pelayanan Umum di Indonesia. Jakarta: Bina Aksara.

15. Budiman, N. (1996). Pengantar Kebijakan Publik. Jakarta: PT. Raja Grafindo Persada.

16. Surjadi. (2009). Pengembangan Kinerja Pelayanan Publik. Bandung: Refika Aditama.

17. Edward III, G. C. (1980). Implementing Public Policy. Washington DC: Congressional Quarterly Press.

18. Widodo, J. (2001). Etika Birokrasi dalam Pelayanan Publik. Malang: CV. Citra Malang.

19. Sinambela, L. P. (2008). Reformasi Pelayanan Publik. Jakarta: Bumi Aksara. 